the plan that breakdown or immobilization is most likely to occur. It is one thing for persons who have received this training in small group leadership and membership to be more effective in their existing human relationships; it is far more threatening to the power structure of the church when a training group plans and sponsors some large scale educational activities. The authors evidently recognize this danger when they say: "Care is taken to avoid conflict with the responsibilities of church administrators and official church committees who are carrying on the established educational work of the church." (p. 86) Yet, how can there be freedom to meet real needs if so many areas are considered out of bounds for the training group?

The major portion of the book consists of step by step instructions for operating the plan, including detailed directions for conducting both an institute for trainers and a weekend clinic, in each of which this book is used as a text with session by session reading assignments.

It is claimed that the use of the Indiana Plan results in the following kinds of personal growth:

1. Creative self-expression

2. Acceptance of personal responsibility

3. Cooperation in a common task

4. Better communication

5. Self-examination

6. Self-guidance

7. Sensitivity to individual needs

The appendix of this book contains an array of tools including an educational interest survey, questionnaires on church activities and educational topics, a sermon forum program and several evaluation forms.

In short, this book presents not only the general principles of dynamic, participative education, but also specific procedures for implementation.

W. Randolph Thornton

National Council of the Cburches of Christ

\section{EDUCATION AND CHANGES.} By R. A. Hodgkin. London: Oxford University Press, 1957. 150 pp. $\$ 2.50$.

This little book is intended "mainly for those who work in countries where education is part of a process of social change." The author, now headmaster of Abbotsholme School (England) has travelled widely in Africa, the Middle East, and India and for 16 years was associated with a variety of educational enterprises in the Sudan, where he finally became Principal of the Institute of Education at Bakht er Ruda.

His thesis is that the strains and tensions within African and Eastern societies are signs not only of danger but also of life and promise, and that much good may come out of the clash of cultures between Europe and America on the one hand and Asia and Africa on the other, especially if educators and other leaders study and learn to understand the processes of change involved.

This book should appeal to the American reader with a general interest in education for at least two reasons. First, it contains much wise discussion of the meaning and goals of education, whatever its setting; for example, the chapters on "Dialectical Common Sense," "Education and Democracy" and "The Source of Creative Ideas." In the second place, it takes the reader on an intellectual journey to an important part of the world, and introduces him to much thoughtful literature about education now being written by English and South Asian authors. 
At the same time, it should also appeal to the reader with a specialized interest in adult education. The material on the assimilation of new ideas applies as much to the U.S.A. as to Africa. The chapter on adult education is stimulating and the summary on pages 116-117 of ways in which adult teaching differs from the teaching of children is a gem of condensation and insight.

This is neither a book of sophistication nor a manual of practice. But it should be useful to both the practitioner and the sophisticated (often the same person) because it formulates many propositions which the practitioner may apply as a guide in his work and the sophisticated may employ in the development of theory and research. The book concludes with a synopsis which serves as a review of the argument and which may easily be used as a basis for seminar discussions, staff training and related activities.

Howard Y. McClusky

The University of Michigan

\section{WHAT'S HAPPENED TO OUR HIGH SCHOOLS? By Jobn Francis Latimer. Wasbington, D. C.: Public Affairs Press, 1958. \$3.25.}

Dr. Latimer begins his book with the shocking assertion that:

"We, the American people, have failed in our educational responsibilities. We bave failed ourselves, but worse than that, we have failed our children. . . We bave compounded the tragedy by our failure to realize the importance of the curriculum in secondary education, and by our failure to sense the vital connection between education and national security." (p. III. italics in original)

We are not producing the scientists, engineers, and language specialists we must have in our defense against the Russians; and the curriculum of the high school, Dr. Latimer seems to assume, is largely at fault. How the curriculum came to be what it is today is the problem attacked in the book.

The author analyzes the curriculum offerings and subject enrollments in the high schools at approximate ten year intervals from 1899-1890 to 19491950. The data are taken from the reports of the United States Office of Education, and the analysis is in terms of trends in offerings and enrollments in the various subjects. Some attention is given to the preparation, or lack of it, of high school graduates for admission to college and specialization in various fields.

According to Dr. Latimer there has been a shift in emphasis from intellectual (mental) and cultural discipline to "life adjustment"; from solid content to "needs and interests" of pupils. Enrollment in "cumulative subjects"-mathematics, science, and foreign languages-has decreased from 255.5 per cent of pupils enrolled in school in 1910 to 131.1 per cent of those enrolled in 1949. On the other hand, enrollment in the "practical subjects" has increased from 21.7 per cent of pupils enrolled in school in 1900 to 124.4 per cent of those enrolled in 1949. Enrollment in health, music and art has increased from 2.0 per cent of pupils enrolled in school in 1900 to 148.2 per cent of those enrolled in 1949 . The number of subjects offered has increased from 35 , of which 27 were academic, in 1910, to 274 , of which only 59 were academic, in 1949.

As a result of all this a smaller percentage of high school graduates are qualified for solid scholarly pursuits, according to the author. Clearly, something must be done to correct this. 